\title{
The Quality of Integrating, Rationale \& Approach Participation (IRA) Teaching Model Based on Environmental Education: A Research \& Development
}

\author{
Mirawati Abdullah*, Syamsul Bachri Thalib, Gufron Darma Dirawan \\ Postgraduate of Universitas Negeri Makassar, South Sulawesi, Indonesia \\ Received April 26, 2021; Revised June 18, 2021; Accepted July 19, 2021
}

\section{Cite This Paper in the following Citation Styles}

(a): [1] Mirawati Abdullah, Syamsul Bachri Thalib, Gufron Darma Dirawan, "The Quality of Integrating, Rationale \& Approach Participation (IRA) Teaching Model Based on Environmental Education: A Research \& Development," Universal Journal of Educational Research, Vol. 9, No. 8, pp. 1560 - 1571, 2021. DOI: 10.13189/ujer.2021.090808.

(b): Mirawati Abdullah, Syamsul Bachri Thalib, Gufron Darma Dirawan (2021). The Quality of Integrating, Rationale \& Approach Participation (IRA) Teaching Model Based on Environmental Education: A Research \& Development. Universal Journal of Educational Research, 9(8), 1560 - 1571. DOI: 10.13189/ujer.2021.090808.

Copyright $\odot 2021$ by authors, all rights reserved. Authors agree that this article remains permanently open access under the terms of the Creative Commons Attribution License 4.0 International License

\begin{abstract}
Learning products that have been designed and developed by the teacher/researcher must be tested first to determine their quality level before being disseminated to the broader community. This research is a development product testing phase by going through the validity, practicality and effectiveness test phase, which is the final part of a research and development (R\&D) design. There are three groups of participants involved in this study: two validators, five elementary school teachers, and 25 students from Madrasah Ibtidaiyah Negeri 1 Majene, West Sulawesi, Indonesia. Several instruments were used in collecting data in this study, namely: (a) validation sheets, (b) teacher response questionnaires, (c) student response questionnaires, (d) learning implementation observation sheets, and (e) learning outcomes tests. The data that have been collected are then analyzed using a quantitative approach with the help of the SPSS version 20.00 application. The results showed that the Integrating, Rationale and Approach Participation (IRA) learning model was proven to be valid, practical, and effective through a series of tests carried out. Thus, this environment-based IRA learning model can be used by a broader range of users.
\end{abstract}

Keywords Integrating, Rationale, Approach Participation, Environmental Education

\section{Introduction}

The discourse on the environment and its problems have become an essential issue in various forums and policy implementation worldwide in the last decades. This environmental initiative arose some 200 years ago because of the human need to save endangered species [1]. Along with the progress of the times, the reasons for applying care and protection of nature and the environment are increasingly diverse. Since 1970, there have been clear signs indicating the destruction of the planet Earth. Among these signs include: (a) global warming and rising sea levels [2], (b) the problem of plastic waste [3], (c) habitat destruction on a global scale [4], and others.

The environmental damage that has occurred is undeniably caused by human activity. That is, the interactions that occur between humans and nature so far can be said to be unbalanced [5]. Experts emphasize that interactions between humans and nature have contradicting impacts. On the one hand, the environment has a positive influence on humans in general. On the other hand, humans have a negative effect and even cause damage to the environment [6], [7].

To overcome these environmental problems requires understanding and awareness of each individual to maintain and pay more attention to their environment. One of them is by incorporating environmental education 
into the educational curriculum starting from elementary, secondary, to tertiary schools. Environmental education aims to move students from awareness to a state of action to create solutions for current and future environmental problems [8]. Environmental education is also defined as a form of content and pedagogical collaboration that involves students in environmental studies encouraging changes in their behaviour and actions [9].

Although it has been implemented in various educational curricula for a long time, public awareness about the importance of the environment is still shallow. In the school environment alone, students' habits and actions do not reflect the level of environmental awareness. The unsuccessfulness of environmental education has been seen as an education system that still carries an old mindset in its implementation. This conventional mindset is a form of human view and thought which sees that the external environment is problematic and needs to be helped and improved [10]. Humans should realize that the biggest mistake against environmental damage comes from the actions of humans themselves.

Education and learning are complex activities and require extra handling. The lack of awareness of the environment for students is not only caused by the content or the environmental education system that is not yet ideal. Many factors contribute to this problem, one of which is inappropriate learning approaches or methods. Thus, it is necessary to apply a participatory \& rational approach used in integrated learning. The participatory approach is considered an approach that positively impacts academic motivation and student learning outcomes in schools [11].

Student activeness during the learning process is an essential focus in today's 21 st-century learning. This is based on the fact that student participation can encourage various skills, including collaboration skills. As we know that collaboration is one of the skills of this disruptive era besides critical thinking, problem-solving, communication, and creative thinking skills [12], [13]. Mizuko et al. [14] explained that schools must prepare students to contribute and participate in their social life. For this reason, the participatory approach to learning plays an essential role in preparing students to enter the world of work one day [15].

In the Indonesian context, several studies focus on research and development design by developing learning products based on environmental education specifically for elementary school students. A study has developed a learning model based on environmental education specific to the wetland environment [16]. Two other studies have also been carried out for fourth-grade elementary school students to create environmental-based science teaching materials and natural resource materials [17], [18]. One study that raised thematic-integrative learning was conducted by Ariyani \& Wangid [19] for grade 1 elementary school students. This research focuses on developing thematic-integrative teaching materials based on the character values of environmental care and responsibility.

There are still gaps in the number of studies linking thematic-integrative learning with environmental education from some of these studies. Thematic learning is deemed necessary to be studied through various studies because the current curriculum system in Indonesia applies this learning model. For that reason, researchers developed an environment-based learning model combined with an integrative approach, rationale, and approach participation (IRA). The formulation of the problem raised in this article is the level of validity, practicality, and effectiveness of the environmental education-based IRA learning model developed is?

\section{Literature Review}

\subsection{Integrating, Rationale, Approach Participation (IRA)}

The term integrated has various word pairs, for example, integrated curricula, integrated approach, and blended learning. In Indonesia, the term integration has the same meaning as thematic terms. This is based on the implementation of the curriculum in 2013, which focuses on thematic learning. Integrated learning based on the educational philosopher John Dewey is a curriculum context designed in real situations (contextual) to be meaningful to students [20]. This learning is a way of planning and organizing the implementation of a curriculum. This learning focuses on an idea or topic [21]-[23].

Integrated learning is essentially a learning approach that allows students either individually or in groups to seek actively, explore and discover concepts and principles holistically and authentically [24]. Varun [25] states that thematic is described as integrating subjects (two or more) that are interrelated and do not stand alone. This condition impacts students' ability to understand what they are learning becomes more accessible because they are mutually integrated and not separated [26].

Furthermore, the term Rationale is an argument that is the primary reason. The rationale is also defined as a thought or the most fundamental reason. Robinson [27] states that rational is a conceptual framework for analyzing and interpreting curriculum and teaching programs in educational institutions. Furthermore, Haynes et al. [28] argued that rational design is a framework for understanding how theoretical conjectures are translated into artefacts. Moreover, they also say that rational design is a representation or derivative of the logical form of argumentation. Rational design is an assumption about making a design, reasoning and formulating answers to how and why questions are essential for scientific purposes. 
Third, a participatory approach to learning is a process that involves students improving attitudes, knowledge and skills. This approach is complicated because it requires training, design activities and makes relatively much subject matter [29]. Active participation and student involvement in learning are essential factors in measuring the quality of learning. Student participation is related to the marketization of school graduates related to performance, skills, and individualization of student achievement for future success [30]-[32].

The participatory learning approach is adjacent to collaborative or cooperative learning. This approach offers students opportunities beyond mere consultation and promotes students' active participation in the problems that shape their lives [33]. This approach is considered essential because the present and the future require various 21st-century skills consisting of collaboration, creativity, critical thinking, and others [34]. On the other hand, this participatory approach also offers negotiations between teachers and students and between students, explaining what and how to learn about goals, knowledge, skills, and attitudes. [35], [36]. By reviewing each of the definitions and benefits of the three approaches, it is necessary to develop an integrated learning model by prioritizing rational aspects and encouraging students' active participation in class.

\subsection{Teaching Model}

In practice in the field, teachers/lecturers and practitioners often misunderstand the terms between models, approaches, strategies, methods, techniques, and learning tactics. The six terms have quite fundamental differences. The term "model" is defined with several meanings. According to Sagala, quoted by Hasbi [37] there are seven definitions of the word "model", namely: (a) a type or design, (b) a description or analogy that is used to help the visualization process of something that cannot be immediately seen, (c) a system containing assumptions, data, and interferences used to describe an object, (d) a simplified design of the work system, (e) a simplified translation of reality, (f) a description of a system that may be imaginary in nature, and (g) minimized presentation in order to explain and demonstrate the nature of the original form.

The learning model is a plan that can be used to form programs in designing teaching materials and guiding the instructional process [38]. On the other hand, the learning model is interpreted as a pattern or conceptual framework that describes various instruments and procedures for managing learning systematically [39]. The learning model is used as a standard and reference for planning learning, implementing learning, assessing learning outcomes, and developing other learning systems. Also, the learning model can be associated as a strategy based on theory (or the results of research) from educators, psychologists, philosophers, and others that describe how a process is designed for learning [40], [41]. Furthermore, Ellis said that each learning model contains: (a) rationality, (b) a series of steps used by lecturers and students, (c) a description of the appropriate support system, and (d) evaluation methods of student progress.

\subsection{Environmental Education}

Pritchard first proposed environmental education in the formation of The International Union for Protection of Nature and Natural Resources (IUPN) in 1948). Along with its development, the theory of environmental education is divided into three types, namely process theory, discipline, and method theory [42]. However, to date, there is still a lack of complete consensus on the definition of environmental education itself. In essence, environmental education aims to increase environmental literacy for the general public and encourage environmental protection behaviour [43], [44].

Environmental education has been implemented in a monolithic way for a long time and is integrated into other subjects in formal education. Hamzah [45] emphasized that environmental education is often perceived as the same as environmental science. The competencies of the two disciplines are very different even though they have an inseparable relationship, namely environmental education and environmental science (ecology). Environmental education's three main components are holistic and indivisible: biological, non-living, and social [46].

The purpose of environmental education as an educational program is to foster students to have rational and responsible understanding, awareness, attitudes, and behaviour regarding the reciprocal influence between residents and the environment in various aspects of human life [47]. Apart from that, environmental education also aims to equip students with knowledge, values, and skills that promote environmental protection and preservation [48]. In more detail, environmental education aims to: (a) protect human health, (b) promote sustainable development related to environmental protection and pollution prevention about economic development, (c) create interest in a wide variety of jobs in various environmental fields, (d) enhancing learning in all areas of education, and (e) strengthening the desire to protect natural resources for future generations [49].

For this reason, researchers integrate these three aspects into one learning model. The learning model in question refers to the learning model proposed by Joyce et al. Designing a good learning model must look at various considerations, one of which is the target to be achieved in the learning. For example, integrated learning that emphasizes rational aspects and impacts increasing student learning participation is a learning model intended to raise environmental awareness. 


\section{Method}

\subsection{Research Design \& Participants}

Based on the formulation of the problem in the introduction section, the research design used is research and development. This research design is widely used to create an educational and learning product to overcome problems faced by teachers in the field [50]-[52]. Specifically for developing an environment-based IRA learning model, researchers used the development theory proposed by Plomp [53]. According to him, there are several stages in research and development, namely: (a) initial investigation phase, (b) product design phase, (c) realization or reconstruction phase, (d) test, evaluation, and revision phase, and (e) phase implementation.

Concerning measuring the quality of learning products highlighted in this article, the review's focus is only on the fourth phase, namely the test, evaluation, and revision phases. The quality of learning produced in this research and development is tested through three types of tests: validity, practicality, and effectiveness tests [54]. The validity test aims to determine the quality of the product based on expert judgment. Meanwhile, the practicality test involves users responding to product implementation. Finally, the effectiveness test was carried out by looking at student learning outcomes before and after using an environment-based IRA learning model.

In the effectiveness test, one group pretest-posttest is the research design chosen by the researcher. This design only uses a sample of one class by giving treatment to students after the pretest session. That is, before learning using the IRA model is carried out, researchers provide a pretest to see their initial level of understanding. Furthermore, the treatment was given after the pretest session for five face-to-face meetings. The researcher again passed a test (the same question as the pretest) at the 5 th meeting learning. The goal is to see the effect of learning the model.

This study involved several groups of participants, namely groups of experts, teachers, and students. In the validation test phase, two experts are involved in assessing the product developed both in the aspects of content, presentation, and language. The second group of participants involved was the user group, namely five teachers and 25 students. Like the practicality test, the effectiveness test in this study also involved 25 students in grade IV at Madrasah Ibtidaiyah Negeri 1 Majene, West Sulawesi, Indonesia.

\subsection{Data Collection}

\section{1) Data Collection for Validity Test}

For validity testing, there are several instruments used by researchers aimed at experts, namely: (a) a model book validation sheet, (b) a Learning Implementation Plan (LIP) validation sheet, (c) a teacher handbook validation sheet, and (d) a student handbook validation sheet. The validation sheet was submitted to the experts, and the four learning products developed, namely the model book, learning implementation plan (LIP), teacher handbook, and student handbook. After receiving an assessment from the expert, the product is revised based on their suggestions and inputs.

\section{2) Data Collection for Practicality Test}

After being declared valid, the development product was tested in the classroom to see how far it is practical. In the practicality test, researchers used four research instruments, namely: (a) learning implementation observation sheet, (b) learning management observation sheet, (c) teacher response questionnaire, and (d) student response questionnaire. The four instruments were given to teachers and students during the process and at the end of the lesson. Researchers used the IRA model. Observers provide their assessment during the learning process by making observations. Researchers used learning implementation observation sheets and learning management observation sheets. The researcher provided a questionnaire for teachers and students as their response and assessment of the IRA model. This research was conducted at the end of the learning process.

\section{3) Data Collection for Effectiveness Test}

The last test carried out in this study was a test of the effectiveness of the learning products that had been developed. The instrument used in this test is multiple-choice questions with five answer choices. The number of questions used is 20 items that aim to determine students' understanding of the learning material. Before being used, this instrument was first tested with the help of SPSS software to determine the level of validity \& reliability. The results of this test indicate that the questions used in the effectiveness test are proven to be valid and reliable so that they can be used.

\subsection{Data Analysis}

\section{1) Validity Test}

After the data from the validation, the sheet has been collected, and it is then analyzed by determining the average score of each product [55]. The formula used to calculate the average score is:

$$
\bar{X}=\frac{\sum_{j=1}^{n} \bar{A}_{i}}{n}
$$

Information:

$(\bar{X})=$ total mean

$\bar{A}_{i}=$ the average of the $\mathrm{i}$ aspect

$n=$ many aspects

After the overall average score of each product is 
known, it is then compared with the validity category to determine its level of validity [56]. There are four categories of validity used, namely very valid, valid, less valid, and invalid. In detail, the categorization of the level of validity is presented in table 1 .

Table 1. The validity category of development products

\begin{tabular}{ccc}
\hline No. & Score Range & Category \\
1. & $3.5 \leq \mathrm{X} \leq 4.0$ & Very valid \\
2. & $2.6 \leq \mathrm{X}<3.5$ & Valid \\
3. & $1.6 \leq \mathrm{X}<2.5$ & Enough valid \\
4. & $1.0<1.5$ & Unvalid \\
\hline
\end{tabular}

\section{2) The level of practicality}

Several types of instruments were used to measure the practicality of the environment-based IRA learning model, as discussed in the method section. The formula for the validity test above is also used in this practicality test to analyze the average score of the model implementation observation sheet, learning management observation sheet, teacher response questionnaire, and student response questionnaire. After the average score is determined, it is then compared with the practicality categorization table as in table 2 and table 3 [57].

Table 2. Categories of practicality on the teacher response model \& questionnaire sheet

\begin{tabular}{ccc}
\hline No & Score Range & Category \\
1. & $2.5<\mathrm{X} \leq 3.0$ & Works very well/very practical \\
2. & $1.0<\mathrm{X} \leq 2.5$ & Well done/practical \\
3. & $0<\mathrm{X} \leq 1.0$ & Not implemented/not practical \\
\hline
\end{tabular}

Table 3. Practicality categories on the learning management sheet \& student response questionnaire

\begin{tabular}{ccc}
\hline No. & Score Range & Category \\
1. & $3.5 \leq \mathrm{X} \leq 4.0$ & Very practical \\
2. & $2.6 \leq \mathrm{X}<3.5$ & Practical \\
3. & $1.6 \leq \mathrm{X}<2.5$ & Less practical \\
4. & $1.0<1.5$ & It's not practical \\
\hline
\end{tabular}

\section{3) Effectiveness level}

The data of the pretest and posttest learning outcomes were analyzed using SPSS version 20.00. Both data from pretest and posttest were analyzed by calculating the mean and standard deviation. In addition, the researcher also analyzed the data by running a t-test to see the difference between the average pretest and posttest scores. From the test results, it will be known whether this learning model positively affects student learning outcomes.

\section{Results}

\subsection{Validity Test Results}

\section{1) Model book validation}

Table 4. The results of the model book validation

\begin{tabular}{cccc}
\hline No. & Rated aspect & \multicolumn{2}{c}{ Validity } \\
& Average & Category \\
\hline 1. & Supporting theory & 3.7 & Very Valid \\
2. & Syntax & 3.8 & Very Valid \\
3. & Social system & 3.7 & Very Valid \\
4. & Reaction principle & 4.0 & Very Valid \\
5. & Support system & 3.5 & Very Valid \\
6. & Instructional/accompaniment & 4.0 & Very Valid \\
7. & Integration/integration of & 3.7 & Very Valid \\
8. & Implementation of learning & 3.9 & Very Valid \\
9. & Evaluation & 3.8 & Very Valid \\
\hline & Total Average & $\mathbf{3 . 8 1}$ & Very Valid \\
\hline
\end{tabular}

From the results of data analysis in table 4 , it can be described that:

(a) In the aspect of the supporting theory, an average value of 3.7 is obtained, which means that it is in the very valid category. This very valid category has been determined in the method section. It states that the scores are in the range of 3.5 to 4.0 , so it can be noted that this aspect is categorized as very valid.

(b) The syntax aspect of learning in the validation results of this IRA model also falls into the very valid category. This is because the average value of the two experts shows a value of 3.8. It is in the range of $3.5 \leq X \leq 4.0$.

(c) The next aspect that gets an average score with a very valid predicate is the social system aspect. Similar to the supporting theoretical aspect, this aspect obtains an average score of 3.7. The average value is included in the very valid category after being compared with the table of validity criteria in the range of $3.5 \leq X \leq 4.0$.

(d) The fourth aspect in the validation of the IRA learning model book is the principal aspect of reaction or aspects of teacher behaviour. This aspect obtains a maximum average value of 4.0. This means that the two experts give the maximum assessment of the principal aspect of this reaction. Thus, the principal aspect of the reaction is categorized as very valid because the average value is in the range of $3.5 \leq X \leq 4.0$. 
(e) The fifth aspect of the process of validating the IRA learning model book is the support system aspect which is also included in the very valid category. The average score achievement in this aspect is 3.5 , which, when compared with the criteria table in the method section, falls into the very valid category because it is in the same range as in the previous points, which is $3.5 \leq \mathrm{X} \leq 4.0$.

(f) The sixth aspect in the validation of the IRA learning model book is the instructional impact aspect and the accompaniment impact. This aspect obtains the maximum average value, which is 4.0. The average value falls in the range between 3.5 to 4.0 , classified in the very valid category.

(g) The achievement of an average score with a very valid category. It was also achieved in integrating or the aspect of integrating learning content. The experts judged this aspect to be ideal by giving an average score of 3.7. Compared with the validity criteria, the average value falls within the range of $3.5 \leq X \leq 4.0$, which means that this aspect meets the validity criteria.

(h) The next aspect is implementing learning with the activeness of students who get an average score of 3.9 from the ideal score of 4.0. If it is confirmed with the validity category table in chapter III, this aspect is included in the very valid category. This is based on the standard criteria used that the mean value of 3.9 is in the score range $3.5 \leq X \leq 4.0$. This means that the implementation aspect of learning with student activeness fulfils the validity criteria in this validation process.

(i) The last aspect in the process of validating the IRA learning model book is the evaluation aspect. Like the previous aspects, this aspect also fulfils the very valid criteria because it reaches an average value of 3.8. Thus, it can be concluded that this aspect is considered very valid because it is in the score range of $3.5 \leq X \leq 4.0$.

(j) Based on the average value of all aspects of the book validation of the IRA learning model, the cumulative average value is 3.81 . The achievement of this average value indicates that the IRA learning model book is categorized as very valid because it lies in the range $3.5 \leq \mathrm{X} \leq 4.0$. Thus, it can be concluded that the IRA learning model book is very valid and can be used without improvement based on the judgments of two experts.

\section{2) Teacher handbook validation}

Table 5 shows that it is concluded that the overall book validation results obtained a score of 3.6. This average score achievement is categorized as very valid because it is in the score range of $3.5 \leq \mathrm{M} \leq 4.0$. The two experts gave almost uniform assessments so that each aspect achieved a fairly good score. The content feasibility aspect obtained an average score of 3.8, the language aspect was 3.0, and the presentation aspect was 4.0. Thus, it can be concluded that the development result teacher handbook is considered very valid.

Table 5. The results of the teacher's handbook validation

\begin{tabular}{cccc}
\hline \multirow{2}{*}{ No. } & \multirow{2}{*}{ Rated aspect } & \multicolumn{2}{c}{ Validity } \\
& & Average & Category \\
\hline 1. & Content eligibility & 3.8 & Very valid \\
2. & Language component & 3.0 & Valid \\
3. & Presentation aspect & 4.0 & Very valid \\
\hline & Total Average & $\mathbf{3 . 6}$ & Very valid \\
\hline
\end{tabular}

\section{3) Validate student handbooks}

Table 6. The results of the student handbook validation

\begin{tabular}{cccc}
\hline No. & Rated aspect & \multicolumn{2}{c}{ Validity } \\
& & Average & Category \\
\hline 1. & The truth of the content & 3.8 & Very Valid \\
2. & Up-to-date content & 3.7 & Very Valid \\
3. & Benefits of content & 4.0 & Very Valid \\
4. & Aspects of language & 3.5 & Very Valid \\
\hline & Total Average & $\mathbf{3 . 7 5}$ & Very Valid \\
\hline
\end{tabular}

The following validated learning product is a student handbook. The results of the validation analysis of the student handbook as a whole are presented in table 6 . From table 6 , it can be said that the student handbook is declared valid based on the judgment of the experts. The cumulative average score on the validation of the book is 3.75 with each aspect such as (a) the correctness aspect of the content is 3.8 , (b) the up-to-date aspect of the content is 3.7 , (c) the benefit aspect of the content is 4.0 , and (d) the aspect of the language aspect of 3.5. Thus, it can be concluded that the level of validity in the student handbook is "very valid" because the average score is 3.75 in the range of $3.5 \leq \mathrm{M} \leq 4.0$.

\section{4) Validation of Learning Implementation Plan (LIP)}

Table 7. Results of the validation of the Learning Implementation Plan (LIP)

\begin{tabular}{cccc}
\hline \multirow{2}{*}{ No. } & Rated aspect & \multicolumn{2}{c}{ Validity } \\
& & Average & Kategori \\
\hline 1. & Format & 3.5 & Very Valid \\
2. & Contents & 4.0 & Very Valid \\
3. & Language & 3.5 & Very Valid \\
\hline & Total Average & $\mathbf{3 . 6}$ & Very Valid
\end{tabular}

As the validation of teaching materials for teachers and students, the results of the validation of the LIP for the IRA learning model also showed a cumulative average value of 4.0. In table 7 indicates that the LIP's learning 
model can be used without revising both major and minor revisions. The three aspects in the assessment above obtained a maximum score of 4 in format, content, and language aspects. All three are categorized as very valid because the cumulative average value and each aspect are in the range of $3.5 \leq \mathrm{M} \leq 4.0$.

\subsection{Practicality Test Results}

\section{1) Observation of model implementation}

Practicality testing is carried out using several techniques, namely: (a) providing learning implementation observation sheets, (b) learning management observation sheets, (c) teacher response questionnaires, and (d) student response questionnaires. From the results of the analysis of the implementation of learning observations, it was obtained a cumulative average score of 2.5. This means that the average score in table 8 states that the environmental education-based IRA learning model has proven to be very practical because all aspects of the observation are carried out entirely.

Table 8. Observation results of the model implementation

\begin{tabular}{cccc}
\hline \multirow{2}{*}{ No. } & Rated aspect & \multicolumn{2}{c}{ Practicality } \\
& & Average & Category \\
\hline 1. & Syntax & 2.48 & Very practical \\
2. & Social system & 2.6 & Very practical \\
3. & Reaction principle & 2.76 & Very practical \\
4. & Support system & 2.3 & Very practical \\
\hline & Total average & $\mathbf{2 . 5}$ & Very practical \\
\hline
\end{tabular}

\section{2) Observation of learning management}

Table 9. Results of learning management observations

\begin{tabular}{cccc}
\hline No. & Rated aspect & \multicolumn{2}{c}{ Practicality } \\
& & Average & Category \\
\hline 1. & Initial activity & 3.6 & Very practical \\
2. & Core activities & 3.5 & Very practical \\
3. & Class situation & 3.95 & Very practical \\
\hline & Total average & $\mathbf{3 . 7}$ & Very practical \\
\hline
\end{tabular}

Furthermore, the practicality test was carried out by analyzing the learning management observation sheet. From the results of the analysis of the overall learning management test shown in table 9 above. In the initial activity component, the average score obtained was 3.6, while in the core activity component was 3.5. Likewise, for the class atmosphere component, the average score got was 3.95. From the combination of these three scores, the cumulative average score was obtained of 3.7. The cumulative score is in the "very good" category because it ranges from $3.5 \leq X \leq 4.0$. Thus, this environmental education-based IRA learning model has proven practical because of the positive response from the teachers through the observation sheet.

\section{3) Questionnaire for teacher responses}

(k) Furthermore, the practicality test was carried out by analyzing the learning management observation sheet. From the results of the analysis of the overall learning management test shown in table 9 above. In the initial activity component, the average score obtained was 3.6, while the core activity component was 3.5. Likewise, for the class atmosphere component, the average score got was 3.95. From the combination of these three scores, the cumulative average score was obtained of 3.7. The cumulative score is in the "very good" category because it ranges from $3.5 \leq \mathrm{X} \leq 4.0$. Thus, this environmental education-based IRA learning model has proven practical because of the positive response from the teachers through the observation sheet.

Table 10. The results of the teacher response questionnaire analysis

\begin{tabular}{cccc}
\hline \multirow{2}{*}{ No. } & Rated aspect & \multicolumn{2}{c}{ Practicality } \\
& & Average & Category \\
\hline 1. & Learning objectives & 2.9 & Very Good \\
2. & Order of delivery & 2.6 & Very Good \\
3. & Learning methods & 2.7 & Very Good \\
4. & Learning Media & 2.6 & Very Good \\
4. & Time Allocation & 3.0 & Very Good \\
\hline & Total rata-rata & $\mathbf{2 . 8}$ & Very Good \\
\hline
\end{tabular}

\section{1) Student response questionnaire}

Table 11. Results of the student response questionnaire analysis

\begin{tabular}{cccc}
\hline No. & Questionnaire questions & \multicolumn{2}{c}{ Practicality } \\
Average & Category \\
\hline 1. & $\begin{array}{c}\text { Textbooks are easy to use / } \\
\text { practical }\end{array}$ & 4.0 & Very Good \\
2. & $\begin{array}{c}\text { The terms used are easy to } \\
\text { understand }\end{array}$ & 3.76 & Very Good \\
3. & $\begin{array}{c}\text { Textbooks help students } \\
\text { understand the material } \\
\text { Interesting teaching } \\
\text { materials }\end{array}$ & 4.0 & Very Good \\
4. & 3.5 & Very Good \\
\hline & Total average & $\mathbf{3 . 8 1 5}$ & Very Good \\
\hline
\end{tabular}

The response data of 25 students were analyzed and determined by the mean score of the respondents. Table 11 shows that the overall student response score average was 3,815 from a maximum score of 4.0. These results indicate that the student response to this environment-based IRA learning model is very good. Thus, if the score is compared with the table for the category of narcotics in the method section, it can be stated that this product is considered very good/very practical because the score is in the range of 3.5 $\leq \mathrm{M} \leq 4.0$. 


\subsection{Effectiveness Test Results}

The effectiveness test is the last test to see the quality of the learning products that have been developed. Researchers conducted trials through pretest sessions, treatment with environment-based IRA learning models, and post-test sessions in this phase. The learning tests from the two sessions were then analyzed by running the t-test using SPSS software. The results of paired sample statistics are presented in table 12 .

Table 12. Paired sample statistics

\begin{tabular}{cccccc}
\hline & Mean & N & $\begin{array}{c}\text { Std. } \\
\text { Deviation }\end{array}$ & $\begin{array}{c}\text { Std. } \\
\text { Error } \\
\text { Mean }\end{array}$ \\
\hline $\begin{array}{c}\text { Paired } \\
1\end{array}$ & Pretest & 68.4000 & 25 & 20.34699 & 4.06940 \\
\hline & Posttest & 92.8000 & 25 & 9.11958 & 1.82392 \\
\hline
\end{tabular}

The results of the statistical analysis output with the help of SPSS as in table 12 show that the descriptive statistical results of the two samples (pretest and posttest) studied indicate that:

(a) The average pretest value on student learning outcomes is 68.4 with a standard deviation of 20.34699 and a mean, standard error of 4.0694

(b) The average posttest score on student learning outcomes reaches 92.8 with a standard deviation of 9.11958 and a mean, standard error of 1.82392

(c) Since there is a difference in the average score between the pretest and posttest (average pretest <average posttest), it can be described that there is a difference in the intermediate learning outcomes between the pretest and posttest scores.

Table 13. Paired sample correlation

\begin{tabular}{cccc}
\hline & $\mathbf{N}$ & Correlation & Sig. \\
\hline $\begin{array}{c}\text { Paires 1 pretest \& } \\
\text { posttest }\end{array}$ & 25 & .214 & .305 \\
\hline
\end{tabular}

Table 13 shows information that the correlation between the two variables, namely the pretest score and the posttest score is 0.214 with a probability value $(\mathrm{Sig})=$. 0.000 . Thus, the results of the paired samples correlations indicate that there is a correlation between the pretest and posttest scores of environmental-based IRA learning, which is significantly related. This is based on the provision that if Sig. $<0.05$, it is stated that there is a relationship between before and after treatment using the environmental education-based IRA learning model.

Table 14 shows the output table of the paired sample test on the learning outcome test. From the table, information is obtained that Sig. (2-tailed) of $0.00<0.05$. There is a difference in the average score between the pretest and posttest on the results of the environmental-based IRA learning test. Thus, it can be concluded that there is an effect of the environment-based IRA learning model on student learning outcomes.

\section{Discussion}

An environmentally based learning model design should seek to bring curriculum theory and policies to make it easier for elementary school/madrasah ibtidaiyah teachers to execute them in the field. This is because teachers have difficulty changing the position of the idea to an actual implementation form in the classroom [58][61]. For this reason, the design of this IRA learning model is intended to integrate local environmental situations into the school curriculum. This is in line with the opinion of Tovar-galvez [62] which emphasizes environmental learning with various aspects such as (a) project-based learning, (b) comprehensive assessment, and (c) competency-based learning.

One of the phases in research and development is the validity test. This validation process is a prerequisite for determining the quality of the products produced based on the stages in research and development. According to Nieveen [63] the quality of development products is determined by three types of tests: validation, practicality, and effectiveness tests. This validation test is aimed at several experts to assess whether the product developed has met various criteria and is suitable for use based on the perspective of the validators.

The validation process usually uses a validation sheet/questionnaire that assesses several aspects such as (a) language, (b) learning content, (c) presentation, and others. Model books and learning tools are declared valid or very valid if experts believe that the development product can measure the skills specified in the measured domain [64], [65]. In other words, the cavalry is determined from the average score of the experts, which indicates which category the level of validity is.

In general, the validity test usually measures aspects that are divided into construct validity and face validity. In general, construct validity has various criteria that experts must validate, such as (a) model rationality, (b) theoretical and empirical support at each stage, (c) components of the planning \& implementation of the model, (d) the learning environment, and (e) assessment and evaluation [66]. On the other hand, face validity is a type of validity test that measures several aspects, including (a) correctness of concepts, (b) principles in assessment, (c) written format, and (d) language [67]. 
Table 14. Paired samples test

\begin{tabular}{|c|c|c|c|c|c|c|c|c|}
\hline & \multicolumn{7}{|c|}{ Paired Diffences } & \multirow[b]{3}{*}{$\begin{array}{c}\text { Sig. } \\
\text { (2-tailed) }\end{array}$} \\
\hline & \multirow[b]{2}{*}{ Mean } & \multicolumn{6}{|c|}{$\begin{array}{c}95 \% \text { confidence interval } \\
\text { of the difference }\end{array}$} & \\
\hline & & $\begin{array}{c}\text { Std. } \\
\text { deviation }\end{array}$ & $\begin{array}{c}\text { Std. error } \\
\text { mean }\end{array}$ & Lower & Upper & $\mathbf{t}$ & df & \\
\hline Paired 1 pretest-posttest & $-2.440 \mathrm{E} 1$ & 20.44097 & 4.08819 & -32.83762 & -15.96238 & -5.968 & 24 & .000 \\
\hline
\end{tabular}

After being declared valid by experts, the product developed to be tested directly on students as users. This is in line with the statement of Azwar et al. [68] which states that products that have been validated and declared valid by experts can be used for field trials. This means that the product validated can be tested on users, both teachers and students. With a product design that has been validated, of course, it can help students focus more on the learning goals they want to achieve [69].

This environmentally based IRA learning model book is stated to be very practical because the average score in every aspect is in the "very practical" category. Some of the aspects assessed in this model book are supporting theories, syntax, social systems, reaction principles, support systems, instructional and accompanying impacts, integration of material content, implementation of learning, and evaluation. This is in line with the study conducted by Arsyad et al. [70] who validated the model book through eight aspects, namely: (a) rationality, (b) supporting theory, (c) syntax, (d) social system, (e) reaction principle, (f) support system, (g) learning implementation, and (h) assignments \& assessments.

Another way to measure the quality of research products is to test their practicality. The assessment of the product's practicality is based on several aspects that can generate interest for teachers and students in the product [71]. This interest is based on the ease of using products developed in learning activities to achieve the goals. Practicality is seen in the tendency of students to give positive responses to learning using this learning model so that they can understand the material and be involved during the learning process. In other words, a product can be said to be practical if it can be used by teachers and students in normal conditions as indicated by their positive response to the product developed [72].

The last phase that is passed in measuring the quality of the development product is the effectiveness test. This test aims to determine whether there is an increase in student learning outcomes before and after receiving treatment using an environmentally-based IRA learning model. From the results of the effectiveness test using SPSS 20, it was found that this learning model had a potential effect on improving student learning outcomes. From the statistical test, the learning model developed positively impacts the form of an increase in learning outcomes, as seen from the average value in the pretest and posttest sessions.
Environmental-based learning is not only able to improve aspects of student learning outcomes but also includes other aspects. Yesilyurf \& Balakoglu [7] claim that nature and environmental education teaches students skills such as humility and empathy. Also, environmental education in schools and specific communities can boost the interest of young people in promoting the importance of caring for the environment [73], [74]. Thus, the existence of environmental education in schools has a significant role in supporting the survival of humans and their environment. Environmental education can cultivate human beings who are aware, care for, and act positively on their environment.

\section{Conclusions}

In increasing the professionalism and creativity of the teachers, innovation is needed in the learning process. One of the steps that can be taken is to carry out research and development to create products to overcome learning problems. This article reviews the quality of developing products that have designed model books, Lesson Plans (LP), teacher handbooks, and student handbooks. This research is the final part of the research and development ( $R \& R \& D)$ process to test the validity, practicality, and effectiveness of the environmental education-based IRA learning model for Madrasah Ibtidaiyah or at the same level as elementary schools. From the research results, it can be concluded that this learning model is declared valid based on data analysis provided by experts through validation sheets. Also, this learning model has also been proven to be practical and effective after being tested on teachers and a group of students. In the future, this learning product can be tested more widely to promote and improve learning outcomes and student concern for the surrounding environment.

\section{REFERENCES}

[1] G. Thomas, "Facilitation in Education for the Environment," Australian Journal of Environmental Education, vol. 21, pp. 107-116, 2015, doi: 10.1017/50814062600000999.

[2] T. Wigley, "The Paris Warming Targets: Emission Requirements and Sea Level Consequences," Climate 
Change, vol. 147, no. 1-2, pp. 31-45, 2018.

[3] C. Wilcox, E. Van-sebille, and B. D. Hardesty, "Threat of Plastic Pollution to Seabirds is Global, Pervasive, and Increasing," in Proceeding of the National Academic of Sciences, 2015, pp. 11899-11904.

[4] W. R. Turner, M. Oppenheimer, and D. S. Wilcove, "A Force to Fight Global Warming," Nature, vol. 462, no. 7271, pp. 278-279, 2009.

[5] R. Danielraja, "A Study of Environmental Awareness of Students at Higher Secondary Level," Shanlax International Journal of Education, vol. 7, no. 3, pp. 6-10, 2019, doi: 10.34293/education.v7i3.480.

[6] E. E. Egbonyi and U. N. Onnoghen, "From Environmental Awareness to Environmental Responsibility towards a Stewardship Curriculum," Journal of Educational Issues, vol. 2, no. 2, pp. 60-72, 2016, doi: 10.5296/jei.v2i2. 9265.

[7] M. Yesilyurt, M. O. Balakoglu, and M. Erol, "The Impact of Environmental Education Activities on Primary School Students' Environmental Awareness and Visual Expressions," Qualitative Research in Education, vol. 9, no. 2, pp. 188-216, 2020, doi: 10.17583/qre.2020.5115.

[8] North America Association for Environmental Education, Excellence in Environmental Education: Guidelines for Laerning. Washington DC: NAAEE, 2010.

[9] G. D. Boca and S. Saracli, "Environmental Education and Student's Perception, for Sustainability," Sustainability (Switzerland), vol. 11, no. 1553, pp. 1-18, 2019, doi: 10.3390/su11061553.

[10] H. Bai, "A Critical Reflection on Environmental Education During the COVID-19 Pandemic," Journal of Philosophy of Education, vol. 54, no. 4, pp. 916-926, 2020, doi: $10.1111 / 1467-9752.12472$.

[11] S. Dastyar, "The Investigation of the Effectiveness of Participatory Learning Education on Students Motivation and Academic Achievement," International Journal of Advanced Research and Publications, vol. 3, no. 8, pp. 165-170, 2019.

[12] B. Binkley, P. Griffin, B. McGraw, and E. Care, "Defining 21st Century Skills," in Assessment and Teaching of 21st Century Skills, P. Griffin, B. McGraw, and E. Care, Eds. New York: Springer, 2011.

[13] H. Wijaya, I. P. A. Darmawan, S. C. Setiana, H. Helaluddin, and I. T. J. Weismann, "Active Reconnecting Learning Strategies to Increase Student Interest and Active Learning," Indonesian Journal of Instructional Media and Model, vol. 3, no. 1, Art. no. 1, Apr. 2021, doi: 10.32585/ijimm.v3i1.1290.

[14] I. Mizuko, K. Gutierrez, S. Livingstone, B. Penuel, J. Rhodes, and K. Salen, Connect Learning: An Agenda for Research and Design. Irvine: Digital Media \& Learning Research Hub, 2013.

[15] H. Helaluddin, "Redesain Kurikulum Pendidikan Tinggi Islam: Strategi dalam Menyongsong Era Reolusi Industri 4.0," Jurnal Mudarrisuna: Media Kajian Pendidikan Agama Islam, vol. 8, no. 2, pp. 258-277, Dec. 2018, doi: 10.22373/jm.v8i2.3224.

[16] S. Salamah, "Pengembangan Model Pembelajaran Berbasis
Pendidikan Lingkungan dengan Lahan Basah pada Madrasah Ibtidaiyah," EduSains, vol. 10, no. 1, pp. 22-50, 2018, doi: http://dx.doi.org/10.15408/es.v10i1.7217 EDUSAINS

[17] S. Ermanda and N. Ariandani, "Pengembangan Bahan Ajar IPA Berbasis Lingkungan di Sekolah Dasar Negeri 3 Jenggik Tahun Pelajaran 2017/2018," Bada'a: Jurnal Ilmiah Pendidikan Dasar, vol. 2, no. 1, pp. 98-107, 2020, doi: 10.37216/badaa.v2i1.289.

[18] H. Hasnawati, "Pengembangan Bahan Ajar Berbasis Lingkungan Sekitar pada Siswa Kelas IV Sekolah Dasar," Pedagogik Journal of Islamic Elementary School, vol. 3, no. 1, pp. 119-134, 2020, doi: 10.24256/pijies.v3i1. 1134.

[19] Y. D. Ariyani and M. N. Wangid, "Pengembangan Bahan Ajar Tematik-integratif Berbasis Nilai Karakter Peduli Lingkungan dan Tanggung Jawab," Jurnal Pendidikan Karakter, vol. 6, no. 1, pp. 116-129, 2016, doi: 10.21831/jpk.v0i1.10737.

[20] T. Dewdwn, "Relevant, Challenging, Integrative and Design: Perspectives from Theory and Practice for Middle Level Australia," Journal of Educational Researcher, vol. 34, no. 2, 2007.

[21] E. M. Arce, Curriculum for Young Children: An Introduction. New York: Delmar Cengage Learning, 2000.

[22] D. M. M. Zin, S. Mohamed, M. I. A. M. Kashim, E. A. Jamsari, A. F. Kamaruzaman, and Z. A. Rahman, "Teachers' Knowledge and Practice in Implementing the Thematic Approach in Pre-school," International Journal of Civil Engineering and Technology, vol. 10, no. 1, pp. 1870-1881, 2019.

[23] H. L. Jackman, Early Education Curriculum: A Child's Connection to the World. New York: Delmar Thomson Learning, 2001.

[24] N. Hidayat, "Pengembangan Pembelajaran Terpadu Model Connected untuk Meningkatkan Hasil Belajar Siswa dalam Mata Pelajaran Ilmu Pengetahuan alam (Studi Pengembangan pada Madrasah Tsanawiyah di Kabupaten Gunung Kidul)," Jurnal Inovasi Kurikulum, vol. 1, no. 4, 2009.

[25] V. Ashokan, "Thematic Approach for Effective Communication in ECCE," International Journal of Education and Psychological Research (IJEPR), vol. 3, no. 3, pp. 49-51, 2014.

[26] D. M. M. Zin, S. Mohamed, K. A. Bakar, and N. K. Ismail, "Further Study on Implementing Thematic Teaching in Preschool: A Needs Analysis Research," Creative Education, vol. 10, pp. 2887-2898, 2019, doi: 10.4236/ ce.2019.1012214.

[27] G. Crees, C. Crees, and E. Robinson, Songs from Around The World: for Young Children. Australia: Gary and Carol Crees Publisher, 2010.

[28] R. Haynes, M. B. Paula, and M. C. John, "Scientific Design Rationale," Journal Artificial Intelligence for Engineering Design, Analysis and Manufacturing, vol. 22, pp. 359-373, 2008.

[29] N. R. Ciobanu, "Active and Participatory Teaching Methods," European Journal of Education, vol. 1, no. 2, pp. 69-72, 2018. 
[30] P. Carey, "Students As Co-producer in A Marketised Higher Education System: A Case Study of Students' Experience of Participation in Curriculum Design," Innovations in Education and Teaching International, vol. 50, no. 3, pp. 250-260, 2013, doi: 10.1080/14703297.2013.796714.

[31] N. Zepke, "Student Engagement in Neo-liberal Times: What is Missing?," Higher Education Research \& Development, vol. 37, no. 2, 2018, doi: 10.1080/07294360.2017.1370440.

[32] U. Bergmark and S. Westman, "Student Participation within Teacher Education: Emphasising Democratic Values, Engagement and Learning for a Future Profession," Higher Education Research and Development, pp. 1352-1365, 2018, doi: 10.1080/07294360.2018.1484708.

[33] A. Ameri-Golestan and M. Nezakat-Alhossaini, "Long Term Effects of Collaborative Task Planning Vs. Individual Task Planning on Persian Speaking EFL Learners' Writing Performance," Research in applied lingusitics, vol. 8, no. 1, pp. 146-164, 2017, doi: 10.22055/rals.2017.12617.

[34] H. Vartiainen, "Designing Participatory Learning," in International Conference on Educational Technologies and Sustainability, Technology and Education, 2014, pp. 105112, doi: 10.1007/978-3-319-57070-9_21.

[35] D. Nunan, The Learner Centered Curriculum. Cambridge, United State: Cambridge University Press, 1988.

[36] A. Philominraj, M. Bertilla, and R. Ranjan, "Participatory Learning: An Appealing Classroom Method to Foster English Language Teaching," Revista Espacios, vol. 41, no. 6, p. 10, 2020.

[37] Hasbi, "Pengembangan Model Pembelajaran Berbasis Masalah Menggunakan Lingkungan Sekitar untuk Meningkatkan Ketuntasan Belajar di Sekolah Dasar," Makassar, 2016.

[38] Y. P. Pateliya, "An Introduction to Modern Models of Teaching," International Journal for Research in Education, vol. 2, no. 2, pp. 125-129, 2013.

[39] H. Said, "Pengembangan Model Pembelajaran Virtual untuk Meningkatkan Efektivitas Pembelajaran pada Madrasah Negeri di Kota Parepare," Lentera Pendidikan, vol. 17, no. 1, pp. 18-33, 2014.

[40] S. S. Ellis, Model of Teaching: A Solution to the Teaching Style/Learning Style Dillema. Greenwich Connecticut: The Association for Supervision and Curriculum, 1979.

[41] B. Joyce, M. Weil, and E. Calhoun, Models of Teaching, Delapan. Yogyakarta: Pustaka Pelajar, 2011.

[42] P. Stern, "Toward Theory of Environmentally Significant Behavior," Journal of Social Issues, vol. 56, pp. 407-424, 2000.

[43] Y. Wang, "Exploration and Analysis of the Concept of Environmental Education," Computer Education Research, vol. 1, pp. 18-22, 2003.

[44] E. Wu, J. Cheng, and J. Zhang, "Study on Environmental Education Demand \& Environmental Literacy Assessment of Citizens in Sustainable Urban Construction in Beijing," Sustainability, vol. 12, no. 241, pp. 1-23, 2020, doi: 10.3390/su12010241.
[45] S. Hamzah, Pendidikan Lingkungan: Sekelumit Wawasan Pengantar. Bandung, Indonesia: Refika Aditama, 2013.

[46] J. A. Palmer and N. Philip, The Handbook of Environmental Education. New York: Taylor \& Francis, 2003.

[47] S. Pratomo, "Model Pembelajaran Tematik dalam Pendidikan Lingkungan Hidup (PLH) di Sekolah Dasar," Jurnal Pendidikan Dasar, vol. 11, pp. 8-15, 2009.

[48] K. R. Peter, "The Benefit of Mainstreaming Environmental Education in the School Curriculum," Research Journal in Organizational Psychology \& Educational Studies, vol. 2, no. 2, pp. 54-59, 2013.

[49] A. Karatas and E. Karatas, "Environmental Education As a Solution Tool for the Prevention of Water Pollution," Journal of Survey in Fisheries Sciences, vol. 3, no. 1, pp. 61-70, 2016, doi: 10.18331/sfs2016.3.1.6.

[50] W. R. Borg and D. M. Gall, Educational Research. New York: Longman, 1989.

[51] S. Thiagarajan, D. S. Semmel, and M. I. Semmel, Instructional Development for Training Teachers of Exceptional Children. Blomington Indiana: Indiana University, 1974.

[52] W. Dick, L. Carey, and J. O. Carey, The Systematic Design of Instruction. New York: Longman, 1985.

[53] T. Plomp, "Educational Design: Introduction," in Educational \& Training System Design: Introduction, T. Plomp, Ed. Lemma: University of Twente, 1997.

[54] N. Nieveen, "Prototyping to Reach Product Quality," in Design Approaches and Tool in Education and Training, J. Van Den Akker, R. M. Branch, K. Gustafson, and Nienke Nieveen, Eds. Boston: Kluwer, 1999.

[55] A. S. Ahmar and A. Rahman, "Development of Teaching Material using An Android," Global Journal of Engineering Education," vol. 19, no. 1, pp. 72-76, 2017.

[56] T. Supartini, I. T. J. Weismann, H. Wijaya, and H. Helaluddin, "Development of Learning Methods through Songs and Movement to Improve Children's Cognitive and Psychomotor Aspects," European Journal of Educational Research, vol. 9, no. 4, pp. 1615-1633, 2020, doi: 10.12973/eu-jer.9.4.1615

[57] H. Hasmawaty, H. Syam, and A. Saman, "Validity, Practicality, and Effectiveness: The Last Step in Development of Entrepreneurship Education Based Role-Playing for Kindergarten," Universal Journal of Educational Research, vol. 8, no. 12B, pp. 8092-8101, 2020. Doi: 10.13189/ujer.2020.082611

[58] L. Briggs, N. Trautmann, and C. Fournier, "Environmental Education in Latin American and the Carribean: The Challenges and Limitations at Conducting a Systematic Review of Evaluation Research," Environmental Education Research, vol. 24, no. 12, pp. 1631-1654, 2018, doi: 10.11080/13504622.2018.1499015.

[59] A. Geli, L. Collazo, and I. Mola, "The Evolution of Embedding Sustainability in the Higher Education Curriculum in Spain," Revista de Educacio Ambiental Sostenibilidad, vol. 1, no. 1, 2019.

[60] M. Sanuca, "The Environmental Education, A Challenge 
for the Professional's Formation in Angola," VARONA: Revista Cientifico Metodologica, vol. 67, pp. 1-10, 2018.

[61] Y. Tian and C. Wang, "Environmental Education in China: Development, Difficulties and Recomendations," Journal of Social Studies, vol. 3, no. 1, pp. 31-43, 2016.

[62] J. C. Tovar-Galvez, "Bringing Environmental Education to the Curriculum: Practical Emergent from Teaching Experiences and Research," Interdisciplinary Journal of Environmental and Science Education, vol. 17, no. 3, pp. 1$12,2021$.

[63] S. Ramadhan, D. Mardapi, Z. K. Prasetyo, and H. B. Utomo, "Development of An Instrument to Measure The Higher Order Thinking Skill in Physics," European Journal of Educational Research, vol. 8, no. 3, pp. 743-751, 2019, doi: 10.12973/eu-jer.8.3.743.

[64] N. Kholis, B. Kartowagiran, and D. Mardapi, "Development and Validation of An Instrument to Measure A Performance of Vocational High School," European Journal of Educational Research, vol. 9, no. 3, pp. 955-966, 2020, doi: 10.12973/eu-jer.9.3.955.

[65] T. Plomp, Educational Design Research: An Introduction. Enschede: Netherlands Institute for Curriculum Development, 2013.

[66] J. M. Moulton, C. Cole, N. D. Ridgers, G. Pepin, and L. M. Barnett, "Measuring Movement Skill Perceptions in Preschool Children: A Face Validity \& Reliability Study," Australian Occupational Therapy Journal, vol. 66, no. 1, pp. 13-22, 2019.

[67] A. Azwar, E. Surya, and S. Saragih, "Development of Learning Devices Based on Contextual Teaching and Laerning Model Based on the Context of Aceh Cultural to Improve Mathematical Representation and Self-efficacy Ability of SMAN 1 Peurlak Students," Journal of Education and Practice, vol. 8, no. 2, pp. 186-195, 2017.
[68] E. Wahyuni and P. Prabowo, "Validitas Perangkat Pembelajaran Model Direct Instruction Berbantuan KIT EHUS20 pada Materi Elastisitas," Inovasi Pendidikan Fisika, vol. 9, no. 1, pp. 18-20, 2020.

[69] N. Arsyad, A. Rahman, and A. S. Ahmar, "Developing A Self-learning Model Based on Open Ended Questions to Increase the Students' Creativity in Calculus," Global Journal of Engineering Education, vol. 19, no. 2, pp. 143147, 2017.

[70] M. K. Mustami, S. Syamsudduha, S. Safei, and M. I. Ismail, "Validity, Practically, and Effectiveness Development of Bilogy Textbooks Integrated with Augument Reality on High School Students," International Journal of Technology Enhanced Learning, vol. 11, no. 2, pp. 187-200, 2019.

[71] Y. Hala, S. Saenab, and S. Kasim, "Pengembangan Perangkat Pembelajaran Biologi Berbasis Pendekatan Saintifik pada Konsep Ekosistem bagi Siswa Sekolah Menengah Pertama," Journal of Education and Science Technology, vol. 1, no. 3, pp. 85-96, 2015.

[72] A. Yazid, Kevalidan, Kepraktisan, dan Efek Potensial Suatu Bahan Ajar. Palembang: Pascasarjana Universitas Sriwijaya, 2011.

[73] M. E. Bellino and J. D. Adams, "A Critical Urban Environmental Pedagogy: Relevant Urban Environmental Education for and by Youth," The Journal of Environmental Education, vol. 48, no. 4, pp. 270-284, 2017.

[74] J. Buchanan, K. Pressick-Kilborn, and D. Maher, "Promoting Environmental Education for Primary School-aged Students Using Digital Technologies," Eurasia Journal of Mathematics, Science and Technology Education, vol. 15, no. 2, pp. 1-15, 2019, doi: 10.29333/ejmste/100639. 